\title{
Spatial and temporal variations of sedimentation rate in the Timah Tasoh Water Reservoir, Perlis, Malaysia
}

\author{
ZULLYADINI A. RAHAMAN, WAN RUSLAN ISMAIL \\ HydroGeomorphology Research Group, Universiti Sains Malaysia
}

\begin{abstract}
Spatial and temporal variations of sedimentation rate in the Timah Tasoh Water Reservoir, Perlis, Malaysia. Human activities such as logging, land conservation, road construction and other disturbances in watersheds will increase erosion rate and thus the amount of sediment transported into the river that reaches lakes, reservoirs and sea. Accelerated sedimentation rate in the reservoir can significantly reduce a reservoir's surface area, eliminating wetland area surrounding the reservoir and shallow the areas near the shore of the reservoir. A study of sedimentation rate in the Timah Tasoh water reservoir was carried out from May 2001 to April 2002 by means of sediment traps. The aim of this study is to determine the spatial and temporal pattern of sedimentation rates in the reservoir. The sediment traps were installed at five different locations in the reservoir and replaced every month. Gross sedimentation rates measured in the sediment traps vary from about an average of $1.4 \mathrm{~kg} / \mathrm{m}^{2} /$ month or $16.3 \mathrm{~kg} / \mathrm{m}^{2} / \mathrm{yr}$ in the deepest part of the reservoir to about $79.2 \mathrm{~kg} / \mathrm{m}^{2} / \mathrm{yr}$ (monthly average of 6.6 $\mathrm{kg} / \mathrm{m}^{2} / \mathrm{month}$ ) and $47.1 \mathrm{~kg} / \mathrm{m}^{2} / \mathrm{yr}$ (monthly average of $3.9 \mathrm{~kg} / \mathrm{m}^{2} /$ month) near the inlet of the Pelarit River and the Tasoh River respectively. The sedimentation rate near the Pelarit River and the Tasoh River inflow is correlated with the water and suspended sediment discharge in the river, owing to its proximity to the rivers and the flooding effect, mainly during the wet season. The sedimentation rate decreases southward along the reservoir, as a result of increasing distance from the river mouth. The total suspended sediment load of the Upper Pelarit River and the Jarum River flowing into the reservoir is $11.4 \times 10^{3}$ ton/year and $5.41 \times 10^{3}$ ton/ /year respectively.
\end{abstract}

Key words: reservoir sedimentation, sediment trap, sediment discharge, Timah Tasoh, Perlis.

\section{INTRODUCTION}

Disturbances in watersheds, be it naturally or exacerbated by human activities will increase erosion rate. Detachment of particles land surface is known as erosion. Erosion is the wearing away of land by the action of natural processes but it could be greatly accelerated by human activity. Lately activities by human such as land clearing, for logging or urbanization have been reported to contaminate lakes with sediment. The amount of sediment transported into the river that reaches lakes, reservoirs or the sea will also increase due to such disturbances. Heavy sedimentation rate shortens the lifetimes of lakes and reservoirs, destroys the aquatic habitats, reduces the reservoir's storage capacity and reduces the flood control capacity of reservoir (Alin et al. 1999). Sediment transported into the reservoirs due to deforestation, construction and other human activities bring nutrient and toxin bound to them and may retain or release these compounds when they reach the reservoir. Deforestation and erosion will cause the extreme cycles of flood and drought, which bring negative effects to humans, plants and animals living in the ecosystem.

Accelerated sedimentation rate in the reservoir can significantly reduce a rese- 
rvoir's surface area, eliminating wetland area surrounding the reservoir and shallow the areas near the shore of the reservoir. Sedimentation has reduced the size of the Lake Manzala in Egypt by $50 \%$ in only 90 years (Ayers et al. 1996). Worldwide, reservoirs are estimated to be losing its storage capacity because of sedimentation at a rate of one percent a year. In India, the Nizamsagar reservoir in the Andhra Pradesh lost more than $60 \%$ of its capacity over only 40 years (Postel 1999).

Sedimentation rate is a key parameter in understanding the physical regime and the biological and chemical budgets of lakes and reservoirs. Common techniques used in sedimentation rate studies are using sediment coring and radionuclide isotope such as ${ }^{137} \mathrm{Cs}$ (Nishri and Koren 1994; Fernex et al. 2001; White- head et al. 1998; Tanaka et al. 1994). Other technique is to measure sedimentation rate by means of sediment traps, which has become a common practice in limnological research. Koren and Klein (2000) based their method on Hakanson and Jansson (1983) to study the temporal and spatial variations of sedimentation rate in the Lake Kineret, Israel. The objective of this paper is to determine the spatial and temporal variations of sedimentation rate in the Timah Tasoh reservoir, Perlis and the relationship between sedimentation rate and suspended sediment discharge.

\section{STUDY AREA}

The Timah Tasoh reservoir $\left(6^{\circ} 36^{\prime} \mathrm{N}\right.$ and $100^{\circ} 14^{\prime} \mathrm{E}$ ) is located approximately $13 \mathrm{~km}$ north of the Kangar town near the

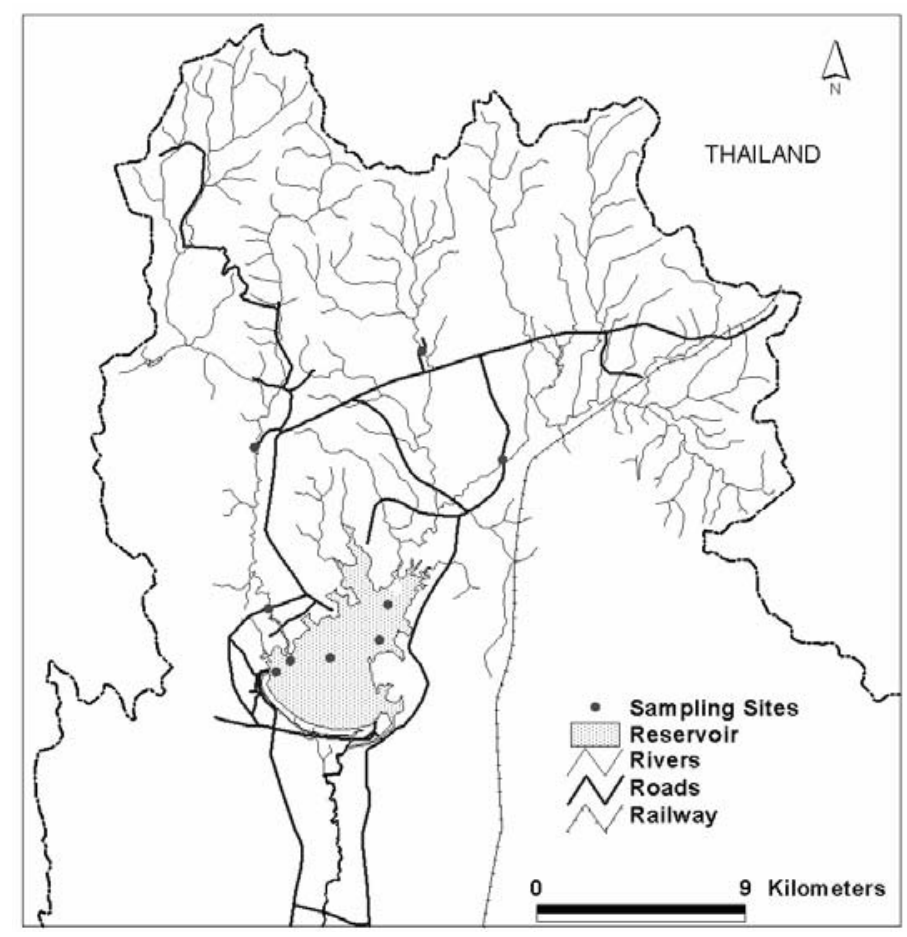

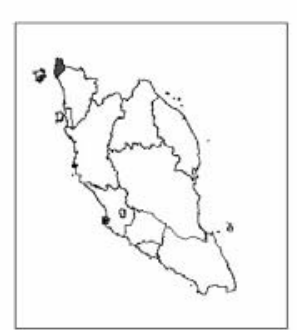

FIGURE 1. Study area 
Thailand border (Fig. 1). The reservoir has a mean surface area of $13.33 \mathrm{~km}^{2}$ and a storage capacity of about 40 million $\mathrm{m}^{3}$. The reservoir receives inputs from two main rivers, the Tasoh and Pelarit, in which have a combined area of $191 \mathrm{~km}^{2}$ and supply approximately 97 million $\mathrm{m}^{3}$ of water into the reservoir annually. The Tasoh River consists of two main sub catchments, the Jarum River and the Chuchuh River, respectively.

The area surrounding the reservoir and its upstream catchments includes mainly agriculture such as rubber, paddy, sugar cane and timber plantations. Urbanisation and some infrastructural development that involved land clearing activities were observed to take place in the catchment area. Such activities in the vicinity of the Padang Besar town influenced the sediment discharge of the Jarum River.

Similarly, the Pelarit River catchment includes area of agricultural land, quarrying and urbanization. The reservoir is shallow with the maximum depth of $10 \mathrm{~m}$ and submergence aquatic plant can be seen along the shoreline and shallow area. At present, the main purpose of the reservoir is to supply water for domestic and industrial use as well as for irrigation and flood control.

\section{METHODS}

Reservoir sedimentation study was initiated in April 2001. The sedimentation rate was measured using the sediment trap (Koren and Klein 2000). The shape and design of the sediment trap was based on the criteria given by Gardner (1980), and has identified three conditions for the design of effective sediment traps:

1. a tube diameter wider than $4 \mathrm{~cm}$;
2. a constant diameter along the tube;

3. an aspect ratio (the ratio between the length of tube and its diameter) ranging between 3 and 15 .

The sediment traps used in this present study met all the three conditions. The trap was built using PVC tube, with a diameter of eight $\mathrm{cm}, 60 \mathrm{~cm}$ long and an aspect ratio of 7.5 (Fig. 2).

Hakanson and Jansson (1983) who studied the physics of vertical and horizontal movements of sediment in water have pointed out the advantages of this method and described the effect of the trap shape and flow conditions on the accuracy of sedimentation rate and sediment composition measurements.

The sediment traps were installed at five different locations in the reservoir and replaced every month. The sediment traps at the Ibus and IP stations were installed to represent the inflow of water from the Tasoh River and the Pelarit River catchments respectively. The Tgh station represents the deepest part of the reservoir while the Out station represents

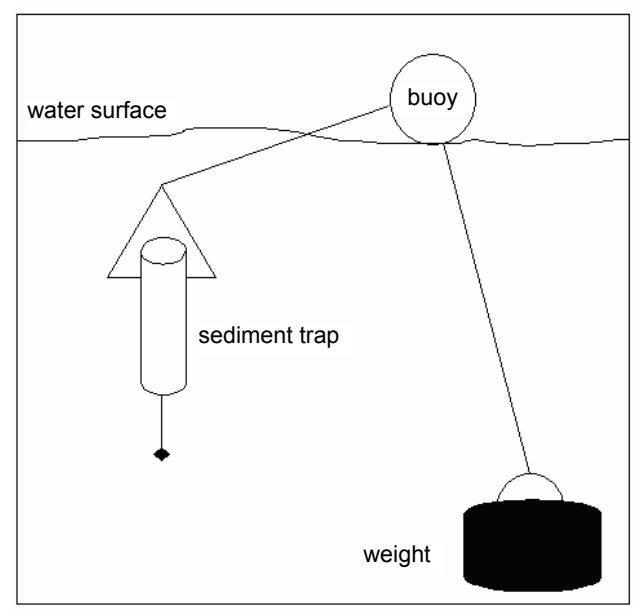

FIGURE 2. Schematic design of sediment trap 
the outflow of water from the reservoir. Water samples accumulated in the trap were filtered using Whatman GFC $47 \mathrm{~mm}$ filter paper and oven dried for 24 hours to determine the weight of sediments. In this study, the sedimentation rate refers to the total amount of material accumulated in the trap.

The water discharge and suspended sediment load was measured at each of the two main rivers flowing into the reservoir. For the Pelarit River catchment, a gauging station was setup at the upper part of the catchment, namely the Upper Pelarit River while for the Tasoh River catchment, the gauging station was at the Jarum River because this station was equipped with hourly water level recorder installed by the Malaysian Department of Drainage and Irrigation. River gauging and water samples were collected every fortnight to determine the sediment concentrations. Water level and velocity were measured to determine the water discharge. Velocity was measured using the SEBA current meter and discharge was measured using the Velocity Area Method (Gordon et al. 1992).

\section{RESULTS AND DISCUSSION}

\section{Water discharge}

The Upper Pelarit River had the highest water discharge during the study period at approximately $37.7 \times 10^{6} \mathrm{~m}^{3}$, slightly higher when compared to the Jarum River which approximately about $32.8 \times 10^{6} \mathrm{~m}^{3}$ (Tab. 1). The average monthly discharge recorded at the Upper Pelarit is $3.14 \times$ $\times 10^{6} \mathrm{~m}^{3}$, with the monthly maximum discharge is $9.08 \times 10^{6} \mathrm{~m}^{3}$, recorded in October 2001. For the Jarum River, the monthly discharge average is $2.73 \times 10^{6} \mathrm{~m}^{3}$ and the maximum monthly discharge is $8.10 \times 10^{6} \mathrm{~m}^{3}$ recorded in November 2001. The lowest monthly discharge at

TABLE 1. Water discharge of the Upper Pelarit River

\begin{tabular}{|c|c|c|c|c|c|}
\hline Month & $\begin{array}{c}\text { Discharge } \\
{\left[10^{6} \mathrm{~m}^{3} / \mathrm{month}\right]}\end{array}$ & $\begin{array}{c}\text { Baseflow } \\
{\left[10^{6} \mathrm{~m}^{3} / \mathrm{month}\right]}\end{array}$ & $\begin{array}{c}\% \\
\text { Baseflow }\end{array}$ & $\begin{array}{c}\text { Stormflow } \\
{\left[10^{6} \mathrm{~m}^{3} / \mathrm{month}\right]}\end{array}$ & $\begin{array}{c}\% \\
\text { Stormflow }\end{array}$ \\
\hline May-01 & 2.60 & 2.33 & 89.8 & 0.27 & 10.2 \\
\hline Jun-01 & 1.89 & 1.89 & 100 & 0 & 0 \\
\hline Jul-01 & 1.67 & 1.67 & 100 & 0 & 0 \\
\hline Aug-01 & 5.88 & 4.30 & 73.1 & 1.58 & 26.9 \\
\hline Sep-01 & 3.26 & 0.45 & 13.7 & 2.82 & 86.3 \\
\hline Oct-01 & 9.08 & 5.67 & 62.5 & 3.41 & 37.5 \\
\hline Nov-01 & 7.95 & 3.06 & 38.4 & 4.89 & 61.6 \\
\hline Dec-01 & 2.54 & 2.26 & 88.9 & 0.28 & 11.1 \\
\hline Jan-02 & 0.93 & 0.93 & 100 & 0 & 0 \\
\hline Feb-02 & 0.33 & 0.33 & 100 & 0 & 0 \\
\hline Mar-02 & 0.23 & 0.23 & 100 & 0 & 0 \\
\hline Apr-02 & 1.37 & 0.90 & 65.9 & 0.47 & 34.1 \\
\hline \hline Total & 37.7 & 24.0 & 63.7 & 13.7 & 36.3 \\
\hline Mean & 3.14 & 2.00 & & 1.14 & \\
\hline Max & 9.08 & 5.67 & & 4.89 & \\
\hline Min & 0.23 & 0.23 & & 0 & \\
\hline
\end{tabular}


TABLE 2. Water discharge of the Jarum River

\begin{tabular}{|c|c|c|c|c|c|}
\hline Month & $\begin{array}{c}\text { Discharge } \\
{\left[10^{6} \mathrm{~m}^{3} / \mathrm{month}\right]}\end{array}$ & $\begin{array}{c}\text { Baseflow } \\
{\left[10^{6} \mathrm{~m}^{3} / \mathrm{month}\right]}\end{array}$ & $\begin{array}{c}\% \\
\text { Baseflow }\end{array}$ & $\begin{array}{c}\text { Stormflow } \\
{\left[10^{6} \mathrm{~m}^{3} / \mathrm{month}\right]}\end{array}$ & $\begin{array}{c}\% \\
\text { Stormflow }\end{array}$ \\
\hline May-01 & 3.97 & 3.43 & 86.5 & 0.54 & 13.5 \\
\hline Jun-01 & 2.83 & 2.64 & 93.3 & 0.19 & 6.7 \\
\hline Jul-01 & 0.55 & 0.55 & 100 & 0 & 0. \\
\hline Aug-01 & 3.10 & 1.67 & 53.9 & 1.43 & 46.1 \\
\hline Sep-01 & 1.28 & 1.28 & 100 & 0 & 0 \\
\hline Oct-01 & 5.37 & 2.19 & 40.9 & 3.17 & 59.1 \\
\hline Nov-01 & 8.10 & 2.52 & 31.1 & 5.58 & 68.9 \\
\hline Dec-01 & 3.23 & 1.89 & 58.6 & 1.34 & 41.4 \\
\hline Jan-02 & 0.67 & 0.67 & 100 & 0 & 0 \\
\hline Feb-02 & 0.56 & 0.56 & 100 & 0 & 0 \\
\hline Mar-02 & 0.52 & 0.51 & 98.4 & 0.01 & 1.6 \\
\hline Apr-02 & 2.60 & 1.23 & 47.4 & 1.37 & 52.6 \\
\hline \hline Total & 32.8 & 19.2 & 58.4 & 13.6 & 41.6 \\
\hline Mean & 2.73 & 1.60 & & 1.14 & \\
\hline Max & 8.10 & 3.43 & & 5.58 & \\
\hline Min & 0.52 & 0.51 & & 0 & \\
\hline
\end{tabular}

both stations was recorded in March 2002 with both stations having the same dry condition with no storm event recorded since January 2002.

The annual average stormflow contribution in the Jarum River is $41.6 \%$, compared to the Upper Pelarit at 36.3\% only. Maximum stormflow at the Jarum River occurred in November 2001 and in September 2001 at the Upper Pelarit River, reflecting high rainfall during the month. As can be seen in Table 2, much of water discharge at both stations is dominated by baseflow, except during the wet season. It is occurred that during the study period, there is a long spell of dry period for almost three months at both stations, since January 2002.

\section{Suspended sediment load}

As expected, the Upper Pelarit River had a suspended sediment load that is higher than the Jarum River catchment. The total suspended sediment load produced at the Upper Pelarit River during the study period was $11.4 \times 10^{3} \mathrm{t}$, compared to $5.41 \times 10^{3} \mathrm{t}$ for the Jarum River (Tab. 3). Storm runoff carried a small proportion of the suspended sediment output of the Jarum River $\left(2.59 \times 10^{3} \mathrm{t}\right.$ or $39.1 \%$ of total load) compared to the Upper Pelarit River, which produced a storm sediment load of $7.98 \times 10^{3} \mathrm{t}$ or $60.8 \%$ of the total load during the study period.

The monthly suspended sediment loads varied, reflecting the seasonal rainfall of the study catchments (Tab. 4). At the Upper Pelarit River, the highest suspended sediment amount was observed in November $2001\left(3.77 \times 10^{3} \mathrm{t}\right)$. During this month, storms contributed as much as $2.63 \times 10^{3} \mathrm{t}$ of suspended sediment load, accounting for $69.7 \%$ of total load of that month. However, the highest monthly 
TABLE 3. Suspended sediment load of the Upper Pelarit River

\begin{tabular}{|l|c|c|c|r|r|r|r|}
\hline Month & $\begin{array}{c}\text { Load } \\
{\left[10^{3} \text { ton }\right]}\end{array}$ & $\begin{array}{c}\text { Sediment } \\
\text { Yield } \\
{\left[\mathrm{t} / \mathrm{km}^{2}\right]}\end{array}$ & Load & \multicolumn{1}{c|}{$\begin{array}{c}\text { Total } \\
{\left[10^{3} \text { ton }\right]}\end{array}$} & $\begin{array}{c}\text { Storm } \\
\text { Yield } \\
{\left[\mathrm{t} / \mathrm{km}^{2}\right]}\end{array}$ & $\begin{array}{c}\% \\
\text { Storm from } \\
\text { Total Load }\end{array}$ & $\begin{array}{c}\% \\
\text { Strom from } \\
\text { Total Month }\end{array}$ \\
\hline May-01 & 0.03 & 0.78 & 0.25 & 0.01 & 0.26 & 0.09 & 34.1 \\
\hline Jun-01 & 0.01 & 0.24 & 0.08 & 0 & 0 & 0 & 0 \\
\hline Jul-01 & 0.01 & 0.24 & 0.08 & 0 & 0 & 0 & 0 \\
\hline Aug-01 & 2.52 & 59.0 & 19.0 & 2.25 & 52.6 & 17.0 & 89.2 \\
\hline Sep-01 & 0.74 & 17.3 & 5.56 & 0.43 & 10.0 & 3.22 & 58.0 \\
\hline Oct-01 & 3.68 & 86.3 & 27.8 & 2.47 & 57.9 & 18.7 & 67.1 \\
\hline Nov-01 & 3.77 & 88.2 & 28.4 & 2.63 & 61.5 & 19.8 & 69.7 \\
\hline Dec-01 & 0.57 & 13.3 & 4.27 & 0.13 & 2.96 & 0.95 & 22.3 \\
\hline Jan-02 & 0.01 & 0.22 & 0.14 & 0 & 0 & 0 & 0 \\
\hline Feb-02 & 0.001 & 0.05 & 0.03 & 0 & 0 & 0 & 0 \\
\hline Mar-02 & 0.001 & 0.03 & 0.02 & 0 & 0 & 0 & 0 \\
\hline Apr-02 & 0.09 & 2.06 & 1.37 & 0.07 & 1.71 & 1.13 & 82.9 \\
\hline \hline Total & 11.4 & 267.6 & & 7.98 & 186.9 & 60.8 & \\
\hline Mean & 0.95 & 22.3 & 7.26 & 0.67 & 15.5 & 5.07 & 35.3 \\
\hline Max & 3.77 & 88.2 & 28.4 & 2.63 & 61.5 & 19.8 & 89.2 \\
\hline Min & 0 & 0.03 & 0.02 & 0 & 0 & 0 & 0 \\
\hline
\end{tabular}

TABLE 4. Suspended sediment load of the Jarum River

\begin{tabular}{|l|c|c|r|r|r|r|c|}
\hline Month & $\begin{array}{c}\text { Load } \\
{\left[10^{3} \text { ton }\right]}\end{array}$ & $\begin{array}{c}\text { Sediment } \\
\text { Yield } \\
{\left[\mathrm{t} / \mathrm{km}^{2}\right]}\end{array}$ & \multicolumn{1}{c|}{ Load Total } & \multicolumn{1}{c|}{ Storm } & $\begin{array}{c}\text { Storm } \\
\text { Yield } \\
{\left[10^{3} \text { ton }\right]}\end{array}$ & $\begin{array}{c}\text { \% Storm } \\
\left.\text { from } / \mathrm{km}^{2}\right]\end{array}$ & $\begin{array}{c}\% \text { Strom } \\
\text { from } \\
\text { Total Load } \\
\text { Total Month }\end{array}$ \\
\hline May-01 & 0.67 & 10.5 & 11.4 & 0.12 & 1.82 & 1.97 & 17.3 \\
\hline Jun-01 & 0.43 & 6.71 & 7.26 & 0.05 & 0.72 & 0.78 & 10.7 \\
\hline Jul-01 & 0.04 & 0.56 & 0.6 & 0 & 0 & 0 & 0 \\
\hline Aug-01 & 0.50 & 7.74 & 8.38 & 0.24 & 3.73 & 4.04 & 48.3 \\
\hline Sep-01 & 0.23 & 3.61 & 3.9 & 0 & 0 & 0 & 0 \\
\hline Oct-01 & 1.00 & 15.6 & 16.9 & 0.56 & 8.68 & 9.4 & 55.7 \\
\hline Nov-01 & 1.29 & 20.1 & 21.8 & 0.75 & 11.7 & 12.6 & 58.1 \\
\hline Dec-01 & 0.48 & 7.42 & 8.03 & 0.23 & 3.56 & 3.85 & 47.9 \\
\hline Jan-02 & 0.02 & 0.3 & 0.19 & 0 & 0 & 0 & 0 \\
\hline Feb-02 & 0.02 & 0.23 & 0.15 & 0 & 0 & 0 & 0 \\
\hline Mar-02 & 0.03 & 0.44 & 0.28 & 0.02 & 0.25 & 0.16 & 55.9 \\
\hline Apr-02 & 0.70 & 10.8 & 6.95 & 0.63 & 9.8 & 6.29 & 90.5 \\
\hline \hline Total & 5.41 & 84.0 & & 2.59 & 40.2 & 39.1 & \\
\hline Mean & 0.45 & 7.00 & 7.14 & 0.22 & 3.35 & 3.26 & 32.0 \\
\hline Max & 1.29 & 20.1 & 21.8 & 0.75 & 11.7 & 12.6 & 90.5 \\
\hline Min & 0.02 & 0.23 & 0.15 & 0 & 0 & 0 & 0 \\
\hline
\end{tabular}


contribution of storm suspended sediment load was produced in August 2001 $(89.2 \%)$. This was due to the availability of new sediment sources which had accumulated in the river channel and from the slopes during the previous wet month to be transported after a long spell of dry condition in June and July 2001 when no storm event occurred. The lowest suspended sediment load was observed in March 2002 (1.4 t), during which no storm event was recorded January 2002.

At the Jarum River, the highest monthly suspended sediment transported was in November $2001\left(1.29 \times 10^{3} \mathrm{t}\right)$, during which $0.75 \times 10^{3}$ t or $12.64 \%$ was contributed from storm events. The lowest monthly suspended sediment load was in February 2002 (15.1 t) reflecting the driest period during the study with no storms recorded since January 2002.

\section{Reservoir sedimentation rate}

The monthly sedimentation rate of all stations is shown in Table 5. IP station recorded the highest annual total sedimentation rate of $79.2 \mathrm{~kg} / \mathrm{m}^{2} / \mathrm{month}$, followed by Ibus $\left(47.1 \mathrm{~kg} / \mathrm{m}^{2} /\right.$ month$)$, Out $(23$ $\mathrm{kg} / \mathrm{m}^{2} /$ month $)$, Tgh $\left(18.8 \mathrm{~kg} / \mathrm{m}^{2} /\right.$ month $)$ and AQ $\left(16.3 \mathrm{~kg} / \mathrm{m}^{2} /\right.$ month $)$. The highest monthly sedimentation rate for most of the sediment trap stations occurred in the month of April 2002, except for the Tgh station that occurred in January 2002.

\section{Sediment trap of IP station}

The relationship between the monthly sedimentation rate $\left(\mathrm{kg} / \mathrm{m}^{2} /\right.$ month) and sediment load is shown in Figure 3. The relationship of sedimentation rate with sediment load was not clear. The sedimentation rate was low during the period of high sediment load (August

TABLE 5. Monthly sedimentation rate of all stations

\begin{tabular}{|c|c|c|c|c|c|}
\hline Station & Ibus & AQ & IP & Tgh & Out \\
\hline Month & {$\left[\mathrm{kg} / \mathrm{m}^{2}\right]$} & {$\left[\mathrm{kg} / \mathrm{m}^{2}\right]$} & {$\left[\mathrm{kg} / \mathrm{m}^{2}\right]$} & {$\left[\mathrm{kg} / \mathrm{m}^{2}\right]$} & {$\left[\mathrm{kg} / \mathrm{m}^{2}\right]$} \\
\hline May-01 & 2.2 & 0.8 & 3.3 & 1 & 0.8 \\
\hline Jun-01 & 2.6 & 0.8 & 2.9 & 1.4 & 1.1 \\
\hline Jul-01 & 4.2 & 1.1 & 4.4 & 1.6 & 1.8 \\
\hline Aug-01 & 3.5 & 1.5 & 3.8 & 1.4 & 1.7 \\
\hline Sep-01 & 1.7 & 1.3 & 2.3 & 1.1 & 1.1 \\
\hline Oct-01 & 1.0 & 0.6 & 1.3 & 0.4 & 0.8 \\
\hline Nov-01 & 1.8 & 0.4 & 3.6 & 0.7 & 0.5 \\
\hline Dec-01 & 3.2 & 0.9 & 9.4 & 2.2 & 0.2 \\
\hline Jan-02 & 3.8 & 1.6 & 12.2 & 3.3 & 2.4 \\
\hline Feb-02 & 2.8 & 1.9 & 10.7 & 2.7 & 3.1 \\
\hline Mar-02 & 7.8 & 2.5 & 12.4 & 1.9 & 3.4 \\
\hline Apr-02 & 12.5 & 2.9 & 12.9 & 1.1 & 6.1 \\
\hline \hline Total & 47.1 & 16.3 & 79.2 & 18.8 & 23.0 \\
\hline Mean & 3.9 & 1.4 & 6.6 & 1.6 & 1.9 \\
\hline Max & 12.5 & 2.9 & 12.9 & 3.3 & 6.1 \\
\hline Min & 1.0 & 0.4 & 1.3 & 0.4 & 0.2 \\
\hline
\end{tabular}




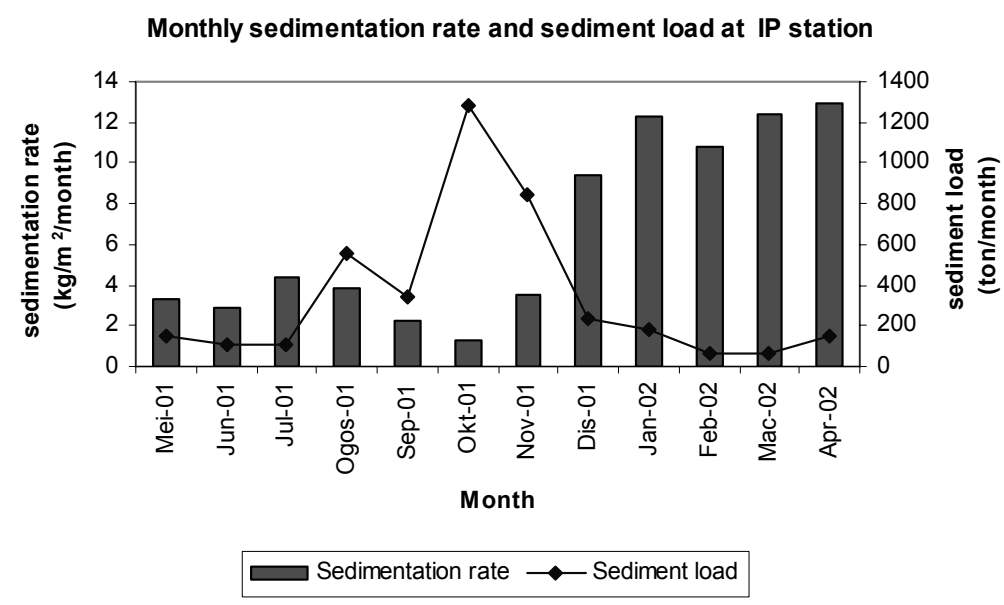

FIGURE 3. Relationship between monthly sedimentation rate and sediment load (IP)

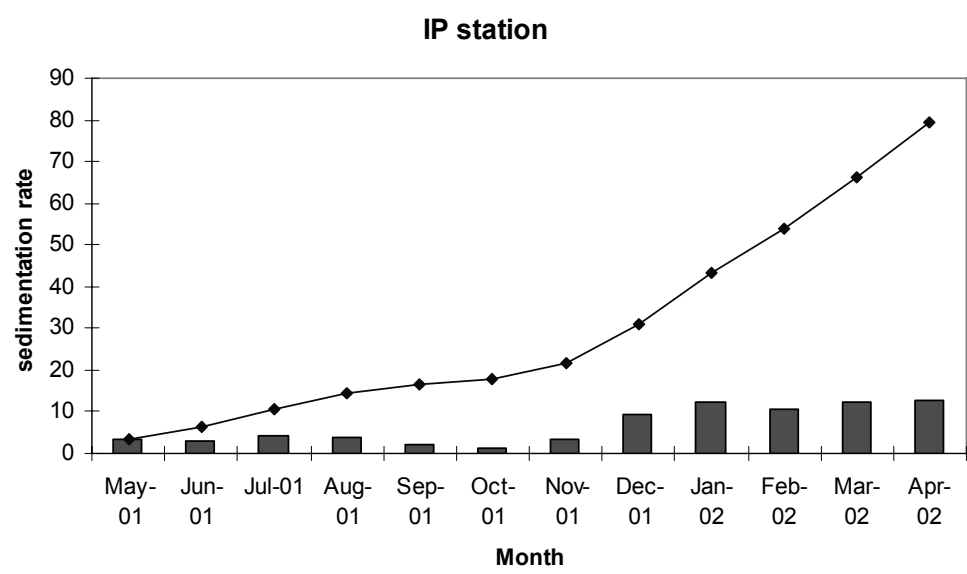

FIGURE 4. Cumulative sedimentation rate during the study period at IP station

to November 2001) and vice versa. This might be influenced by the location of the sediment trap installed at the IP station, which is quite far from the river mouth. The sediment transported by the river cannot reach the sediment trap and as a result, there is no strong relationship between sedimentation rate and sediment load. The behaviour of the sedimentation pattern shows that high sedimentation occurs in the month of December 2001 to April 2002. The amount of sedimentation rate during this period was $57.6 \mathrm{~kg} /$ $/ \mathrm{m}^{2} /$ month or $72.7 \%$ of the total amount of sedimentation accumulated during the study period. The cumulative sedimentation rate is shown in Figure 4.

\section{Sediment trap at Ibus station}

The relationship between the monthly sedimentation rate $\left(\mathrm{kg} / \mathrm{m}^{2} /\right.$ month) and sediment load is shown in Figure 5. 


\section{Monthly sedimentation rate and sediment load at lbus station}

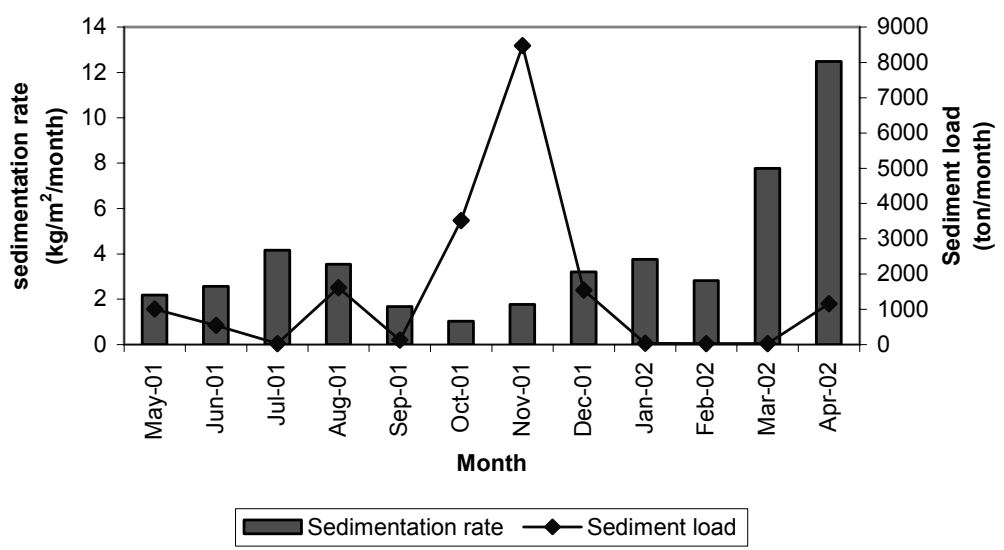

FIGURE 5. Relationship between monthly sedimentation rate and sediment load (Ibus)

\section{Ibus Station}

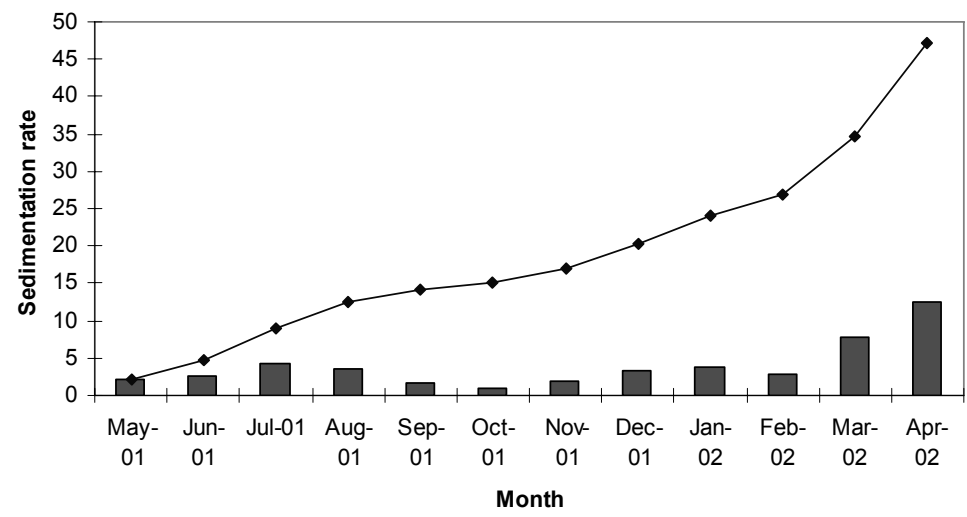

FIGURE 6. Cumulative sedimentation rate during the study period at Ibus station

The same pattern shown at IP station occurred between the relationship of sedimentation rate and sediment load at Ibus station.

The increase in the monthly sediment load will not increase the rate of sedimentation. The behaviour of the sedimentation pattern shows that high sedimentation rate occurs during month of December 2001 to April 2002. The amount of sedimentation rate during this period was $30.1 \mathrm{~kg} /$
$/ \mathrm{m}^{2} /$ month or $63.9 \%$ of the total amount of sedimentation accumulated for the study period. The cumulative sedimentation rate during this study is shown in Figure 6.

\section{Spatial variation of sedimentation rate}

The spatial variation of the sedimentation rate is shown in Figure 7. The highest ave rage of sedimentation rate was $6.6 \mathrm{~kg} / \mathrm{m}^{2} /$ 


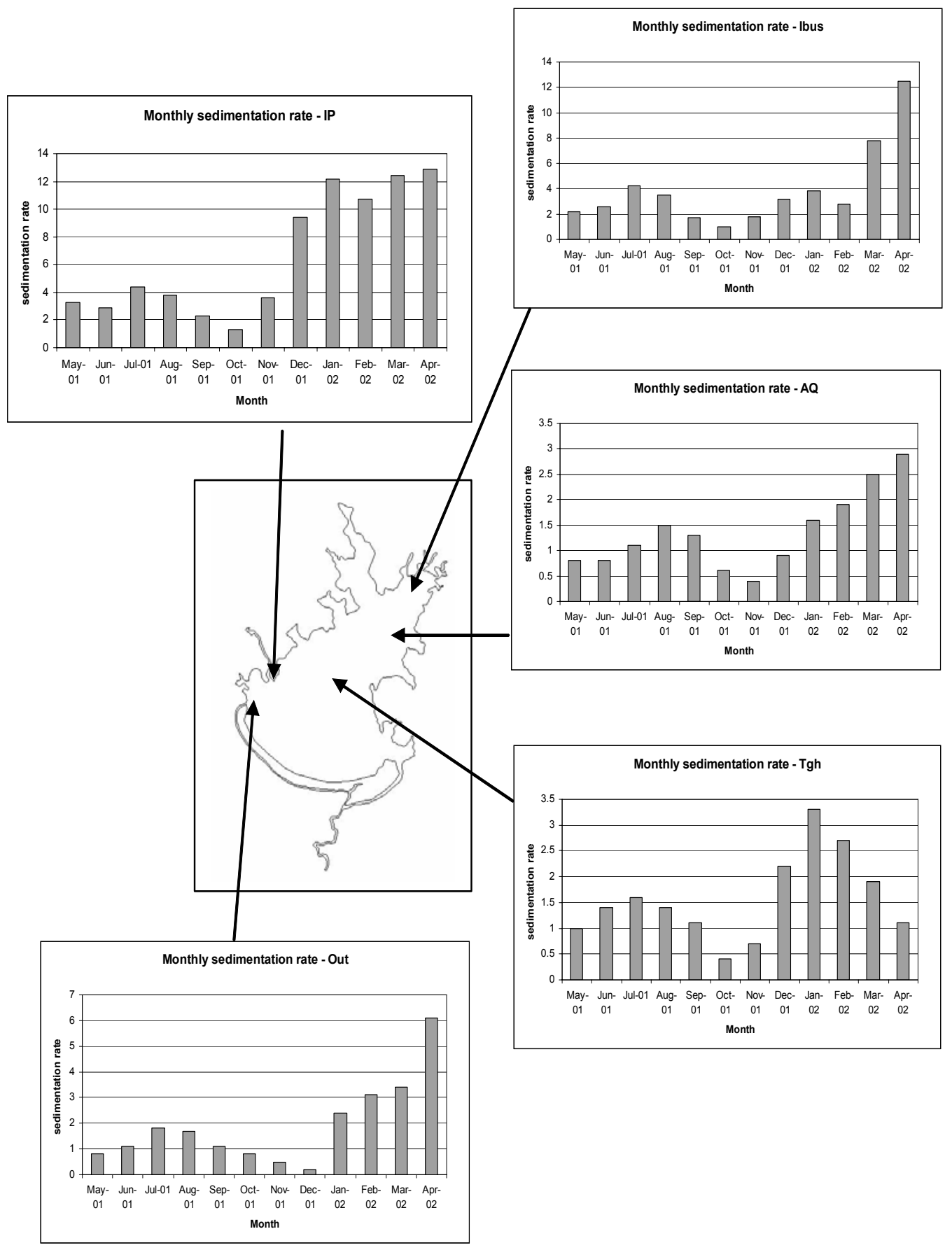

FIGURE 7. Spatial variations of sedimentation rate 
/month at the IP station, which was the main inflow of water and suspended sediment discharge from the Upper Pelarit River catchment area. The Ibus station, which was the main inflow of water and suspended sediment discharge from the Jarum River catchment also have a high average sedimentation rate $\left(3.9 \mathrm{~kg} / \mathrm{m}^{2} /\right.$ /month). The sedimentation rate was high compared to results shown from various studies. For instance, the sedimentation rate in the Lake Pukaki, New Zealand was $28 \mathrm{~kg} / \mathrm{m}^{2} /$ year and the Lake Tikitapu, New Zealand was $0.11 \mathrm{~kg} / \mathrm{m}^{2} /$ year (Whitehead et al. 1998). Tanaka et al. (1994) found that the sedimentation rate in the Lake Mashu, Japan ranging from 6.4 to $7.4 \mathrm{mg} / \mathrm{cm}^{2} /$ year. The result shows that the Timah Tasoh reservoir has a high sedimentation rate compared to other studies.

The AQ, Tgh and Out station shows the lowest sedimentation rate in the reservoir, which the monthly average was $1.4 \mathrm{~kg} / \mathrm{m}^{2} / \mathrm{month}, 1.6 \mathrm{~kg} / \mathrm{m}^{2} /$ month and $1.9 \mathrm{~kg} / \mathrm{m}^{2} /$ month. The results indicate that the sedimentation rate decreased southward along the reservoir, as a result of the increasing distance from the river mouth. The annual sedimentation rate was $16.3 \mathrm{~kg} / \mathrm{m}^{2}$ (AQ), $18.8 \mathrm{~kg} / \mathrm{m}^{2}$ (Tgh) and $23 \mathrm{~kg} / \mathrm{m}^{2}$ (Out). All the sediment trap stations shows that the sedimentation rate was high during the month of December 2001 to April 2002 (Fig. 8).

\section{CONCLUSIONS}

The highest average sedimentation rate was IP station $\left(6.6 \mathrm{~kg} / \mathrm{m}^{2} /\right.$ monthy or $79.2 \mathrm{~kg} / \mathrm{m}^{2} /$ year), while the AQ station shows the lowest average sedimentation rate $\left(1.4 \mathrm{~kg} / \mathrm{m}^{2} /\right.$ month or $16.3 \mathrm{~kg} / \mathrm{m}^{2} /$ year). Throughout the study period, the sedimentation rate was high at the IP and Ibus stations, owing to its proximity to the river mouth of the Pelarit River and the Tasoh River which was the main contributors to the sediment transported into the reservoir. As the distance increase from the river mouth, the sedimentation rate was low, as shown

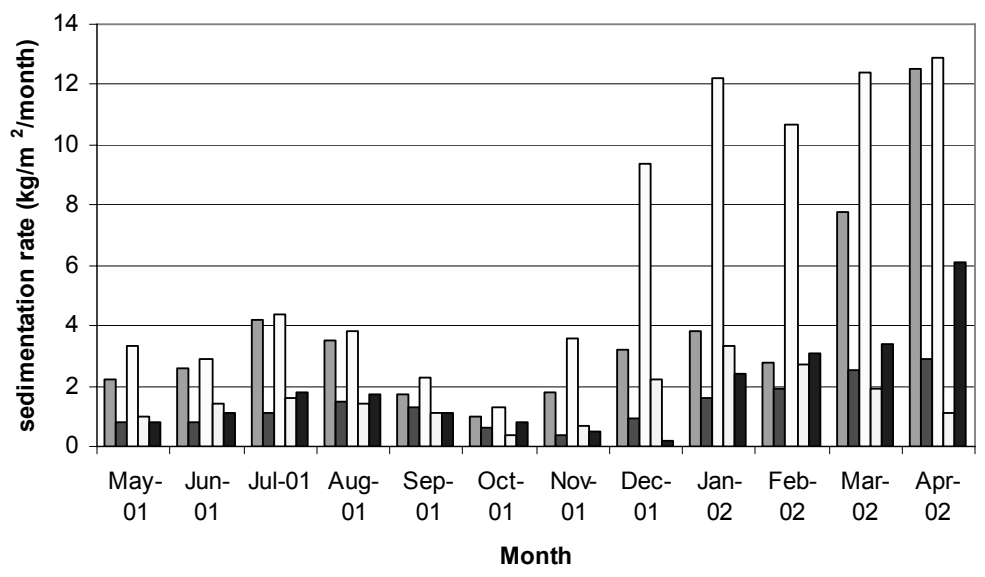

口 lbus $\square$ AQ $\square$ IP $\square$ Tgh $\square$ Out

FIGURE 8. Sedimentation rate during the study period for all stations 
from the sedimentation rate of $A Q$, Tgh and Out stations respectively. The sedimentation rate was high during the month of December 2001 to April 2002. This study shows that there is no strong relationship between sedimentation rate and sediment discharge transported from the catchment area. The Pelarit River and the Tasoh River catchments were the main contributor of sediment transported into the reservoir. The total amount of suspended sediment recorded at the Upper Pelarit River is $11.4 \times 10^{3}$ ton/year compared to the Jarum River is about $5.41 \times 10^{3}$ ton/year.

Acknowledgment: The research project was financed by a research grant from the Ministry of Science and Technology, Malaysia through the IRPA Program 0802-05-0015). The authors wish to thank the Drainage and Irrigation Department of Perlis for providing facilities, rainfall and water level records.

\section{REFERENCES}

ALIN S., COHEN A., 1999: Effect of landscape disturbance on animal communities in Lake Tanganyika, East Africa. Conservation Biology 13(5), 1017-1028.

AYRES W., BUSIA A., DINAR A., HIRJI R., LINTNER S., McCALLA A., ROBULES R., 1996: Integrated lake and reservoir managemant: World Bank approach and experience. World Bank Technical Paper no 358. Washington D.C.

FERNEX F., ZARATE-DEL VALLE P., RAMIREZ-SANCHEZ H., MICHAUD F., PARRON C., DALMASSO J., BARCI-FUNEL G., GUZMAN-ARROYO M., 2001: Sedimentation rates in Lake Chapala (western Mexico): possible active tectonic control. Chemical Geology 177, (3-4), 213-228.

GARDNER W.D., 1980: Sediment traps dynamics and calibrations: A laboratory evaluation. Swiss Journal of Marine Research 38, 17-39.
GORDON N., McMAHON T.A., Finlayson B.L., 1992: Stream Hydrology. John Wiley and Sons, Chichester.

HAKANSON L., JANSSON M., 1983: Principles of Lake Sedimentology. Springer Verlag. New York.

KOREN N., KLEIN M., 2000: Rate of Sedimentation in lake Kineret, Israel: Spatial and Temporal variations. Earth Surface Processes and Landforms, 25, 895-904.

Nishri A., Koren N., 1994: Sediment Transport in Lake Kineret. Proceeding of International Association of Theoretical and Applied Limnology. 25, 2522-2525.

POSTEL S., 1999: Pillar of Sand. Worldwatch Institute. Washington D.C.

TANAKA A., HARUHIKO S., MITSUYUKI S., 1994: Iron and manganese rich sediments as an indicator of hot spring activities at the botton of Lake Mashu, Japan. Geochemical Journal 28(3), 289-306.

WHITEHEAD N.E., DITCHBURN R.G., McCABE W.J., MASON W.J., IRWIN J., PICKRILL R.A., Fish G.R., 1998: Application of natural and artificial fallout radionuclides to determining sedimentation rates in New Zealand. New Zealand Journal of Marine and Freshwater Research 32(3).

Streszczenie: Analiza przestrzenna i czasowa zmienności ilości sedymentu $w$ zbiorniku Timah Tasoh, Perlis $w$ Malezji. Na podstawie szczegółowych łapaczkowych pomiarów terenowych przedstawiono zmiany przestrzenne i czasowe (2001-2002) ilości sedymentu w zbiorniku wodnym Timah Tasoh w Malezji. Łapaczki umieszczone w pięciu punktach zbiornika opróżniano co 5 miesięcy. Zmiany ilości sedymentu wykazano liczbowo na tle ilości dostarczanego rumowiska do zbiornika z rzek Pelarit oraz Jarum.

\section{MS. received April 2010}

Authors' address:

HydroGeomorphology Research Group

Section of Geography, School of Humanities

Universiti Sains Malaysia

11800 Minden, Pulau Pinang.

e-mail: zully@usm.my 